\title{
Assessing soil nutrient change under long-term application of mineral fertilizer micro-dosing to pearl millet [Pennisetum glaucum (L.) R. Br.] on a sahelian sandy soil
}

\section{Sani Issa Mahaman Sanoussi a, *, Fatondji Dougbedji b, Ezenwa Matthew c, A.A. Okhimamhe a, Ali Ibrahim b, Isiah Sule a}

\author{
a Master Research Programme on Climate Change and Adapted Land Use, WASCAL, Federal University of Technology, \\ Gidan Kwano Campus, Minna, Niger State, Nigeria \\ b International Crops Research Institute for the Semi-Arid Tropics, Sahelian Centre Sadore, Niamey, Niger \\ c Department of Soil Science, Federal University of Technology, Gidan Kwano Campus, Minna, Niger State, Nigeria
}

\section{Article Info}

Received : 08.02.2019

Accepted : 23.10.2019

\begin{abstract}
In the Sahel, mineral fertilizer micro-dosing technique is known for its benefits to provide higher nutrient uptake and higher crop yields. A study was set up at ICRISAT research station at Sadoré in Niger, which aims at evaluating the sustainability of the technology in the longterm with emphasis on soil nutrients dynamics. The study has started since 2008 and was laid-out in a randomized complete block design that involved two pearl millet varieties, three planting densities, and four nutrients management options. For this study, a sub-set of the treatments from this long-term experiment was used. The nutrient management factor, which includes 4 levels was considered. The most important findings obtained indicated that the change in soil nutrient was markedly different on the planting hills and that from between hill. The change in soil $\mathrm{pH}-\mathrm{H}_{2} \mathrm{O}$ values on the planting was $-7.06 \%$ for the control plots and $-9.57 \%$ for the plots applied with NPK. The total nitrogen content has dropped in the two different plots. The amplitude of drop has lowered with the application of NPK micro-dosing on the planting hills with respectively $-5.11 \%$ and $-12.45 \%$ in the control plots and the micro-dose plots. Positive change in available $\mathrm{P}$ was significantly observed $(\mathrm{P} \leq 0.05)$ in soil between hill with $1.08 \%$ in the control plots and $15.97 \%$ in the amended plots. Both grain yield and total dry matter showed similar trend in which decreased yield was obvious over the time. In 2008, an average grain yield of $732 \mathrm{~kg}$. ha-1 and $989 \mathrm{~kg}^{-1} \mathrm{ha}^{-1}$ was obtained respectively for the control plots and $6 \mathrm{~g}$ per hill of NPK plots. Whereas in 2016, $146 \mathrm{~kg}^{\mathrm{g}} \mathrm{ha}^{-1}$ and $218 \mathrm{~kg}$. ha- ${ }^{-1}$ were produced respectively for the control plots and the mineral fertilizer micro-dosing plots. These findings indicated that in the Sahel low-input based millet cropping systems, for the mineral fertilizer micro-dosing technology to be sustainable in the long term, the improvement and maintenance of soil fertility should be considered as the cornerstone.
\end{abstract}

Keywords: Fertilizer micro-dosing, sustainability, nutrient mining, long-term, Sahel.

(C) 2020 Federation of Eurasian Soil Science Societies. All rights reserved

\section{Introduction}

In the Sahel, one of the most striking constraints that impede crop productivity is low soil fertility (Bationo et al., 2012; Bielders, 2015). Soil nutrient depletion is a major concern in the same part of the Sahel where low-input small-scale farming systems are predominant (Ibrahim et al., 2016). Reports from Sommer et al. (2013) showed that soil nutrient mining is widespread, with a combined average depletion rate of $\mathrm{N}$, phosphorus (P) and potassium (K) of $54 \mathrm{~kg}$ per hectare per year in sub-Saharan Africa (SSA). Earlier findings

\footnotetext{
${ }^{*}$ Corresponding author.

Master Research Programme on Climate Change and Adapted Land Use, WASCAL, Federal University of Technology, Gidan Kwano Campus, Minna, Niger State, Nigeria

Tel.: +22796094048

E-mail address: mahamansanoussi@gmail.com

e-ISSN: 2147-4249

DOI: $10.18393 /$ ejss.642212
} 
from the study conducted in the long term experiment at Sadore Sahelian Centre of International Crop Research Institute for the Semi-Arid Tropics (ICRISAT) have indicated that N and P nutrients significantly affect the grain yield and total dry matter of pearl millet (Akponikpè, 2008; Suzuki et al., 2016). The technology of fertilizer micro-dosing application, which consists of placing small amounts of fertilizer at the hill of plants (ICRISAT, 2009), is widely recognized as a strategy of nutrient management in integrated manner so as to sustain agronomic productivity (Tabo et al., 2005; Idrissa, 2010; Housseini, 2013; Ibrahim et al., 2015a,b). Recent reports from (Akponikpè et al., 2014; Ibrahim et al., 2015b; Suzuki et al., 2017) confirmed that the use of mineral fertilizer in combination with manure resulted in high crop yields in the Sahel. The benefit in the short term of yields increase and income as result of applying mineral fertilizer micro-dosing has been considerably demonstrated across the Sahel region (Hayashi et al., 2008; Twomlow et al., 2008 ; Aune and Ousman, 2011; Bagayoko et al., 2011 ; Sime and Aune, 2014 ; Ibrahim et al., 2015a,b). However, regardless of the increase in crop yields induced by mineral fertilizer micro-dosing technology, Adams et al. (2016), Camara et al. (2013) and Ibrahim et al. (2016) pointed out the fact that such technology leads to an increase of risk of high nutrient export in low-input millet based cropping system and consequently decreased soil fertility. Ibrahim et al. (2015b) have confirmed that a combined application of fertilizer micro-dosing with cattle manure was unable to balance nutrients exported by the obtained yields. On the other hand, Ibrahim et al. (2015a), showed that an increase of fertilizer application depth ranging from $5-10 \mathrm{~cm}$ gave a significant increase in terms of the root length density while higher depth of the application of fertilizer has given an increase of high yields. Fewer studies if indeed any exists have been carried out in order to determine the sustainability of that technology. It appears that crop roots are mainly concentrated where nutrients are located but lateral root development is also observed. Hence between hill spaces that in the context of micro-dosing does not receive input, which is expected to provide nutrients to crops. Therefore, to have a better understanding of the sustainability of the technology, the best approach would be to study nutrient dynamics at hill level.

For the current study, the general hypothesis drawn is that as result of hill application of the mineral fertilizer micro-dosing, soil nutrients dynamics on the planting hill will be better and different from that of the soil between the planting hills. The objective of the current study was (i), to evaluate the change with respect to nutrients dynamics from the long-term application of mineral fertilizer micro-dosing and thus determining the level of contribution of planting hill focused and between hills focused nutrients dynamics to soil fertility sustainability of the technology; (ii) to evaluate the effect of mineral fertilizer micro-dosing on crop yield over the years.

\section{Material and Methods}

\section{Experimental site description}

The experiment was conducted at the International Crops Research Institute for the Semi-Arid Tropics (ICRISAT) Research Station, Sadoré, Niger (between longitude $13^{\circ} 02^{\prime} 12^{\prime \prime} \mathrm{N}$ to longitude $13^{\circ} 15^{\prime} 00^{\prime \prime} \mathrm{N}$, and Latitude $2^{\circ} 16^{\prime} 01^{\prime \prime} \mathrm{E}$ to latitude $2^{\circ} 17^{\prime} 00^{\prime \prime} \mathrm{E}$ ). The climatic conditions are characterized by a long and hot dry season (November to May) followed by a very short rainy season between June and September. A highly variable rainfall with an annual average of $550 \mathrm{~mm}$ and average temperature is $29{ }^{\circ} \mathrm{C}$ (ICRISAT database 1984-2016). The field trial is a long-term experiment of a combination of pearl millet and mineral fertilizer micro-dosing started since 2008. The soil type in Sadoré is classified as a sandy Arenosol (West et al., 1984). The field experiment had a sandy soil. The soil organic carbon and extractable P contents were very low with $0.22 \%$ and $2.7 \mathrm{mg} \mathrm{kg}^{-1}$ respectively. The total Nitrogen $(\mathrm{N})$ content was low with $179 \mathrm{mg} \mathrm{kg}^{-1}$ and soil pH $\left(\mathrm{H}_{2} \mathrm{O}\right)$ was strongly acidic (Table1).

\section{Experimental set-up}

Data used in the current study derived from a long-term experiment set since 2008 at International Crops Research Institute for the Semi-Arid Tropics (ICRISAT). This experiment was arranged in a randomized complete block design (RCBD) with three replications. The treatments consisted of a factorial combination of (i) four different nutrient management options (control, $3 \mathrm{~g}$ of NPK, $6 \mathrm{~g}$ of NPK and $2 \mathrm{~g}$ of DAP $+1 \mathrm{~g}$ of Urea), (ii) two genotypes of pearl millet (Sadoré local and HKP variety), (iii) three planting densities (Density 1= 5000 hills/ ha); spacing = $1.5 \mathrm{~m} \mathrm{x1} \mathrm{m;} \mathrm{Density} 2=10000$ hills $/$ ha); spacing = $1 \mathrm{~m} \mathrm{x} 1 \mathrm{~m}$ and Density $3=15$ 000 hills $/ \mathrm{ha}$ ); spacing $=0.8 \mathrm{~m} \times 0.8 \mathrm{~m}$ ). Plot dimensions were $6 \mathrm{~m} \times 6 \mathrm{~m}$ and the gross dimension of the experiment was $64 \mathrm{~m}$ x $55 \mathrm{~m}=3569 \mathrm{~m}^{2}$. Then, between row spacing was $1 \mathrm{~m}$ whereas between replication spacing was $2 \mathrm{~m}$ and the useful plot size is $25 \mathrm{~m}^{2}$. 
To achieve the objective of the current study, two treatments were considered (control, without input) and 6 g hill ${ }^{-1}$ of NPK (15-15-15) with one millet variety (local Sadoré) dibbled at spacing of $1 \mathrm{~m} \times 1 \mathrm{~m}$ were used in the present study.

\section{Soil sampling and analysis}

For initial characterization of the experimental field, soil samples were collected before treatments application in 2008. A total of 36 composite soil samples were collected i.e. 12 samples per replication. To evaluate the change in soil chemical characteristics from initial soil status, the soil samples were collected from the plots. In the present study conducted in June 2017, in addition to 4 composite samples collected between the planting hills, 4 planting hills were also selected randomly on which the same core of samples were collected so as to achieve the objectives of the current study. For the samples collection, a graduated aluminum tube was adapted and used as soil sampling auger. In total, 36 soil samples were collected and three cores samples were considered: $0-10 \mathrm{~cm} ; 10-20 \mathrm{~cm}$ and $20-40 \mathrm{~cm}$.

Each sample was analysed for $\mathrm{pH}-\mathrm{H}_{2} \mathrm{O}$ (soil/water ratio of 1:2.5), soil organic carbon was determined with the method described by Walkley and Black (1934), total N by Kjeldahl method (Houba et al., 1995), exchangeable $\mathrm{K}^{+}$and extractable phosphorus were determined respectively by using the extraction method described by van Reeuwijk (2002) and the Bray 1 method (van Reeuwijk, 2002).

\section{Calculation of change in soil nutrient dynamics and statistical analysis}

After the laboratory analysis of the samples, data were processed using Excel. The change in soil nutrients was calculated as follows:

$$
\text { Change in } \mathrm{N}, \mathrm{P}, \mathrm{K}=\frac{(\mathrm{ASNC}-\mathrm{ISNC})}{\mathrm{ISNC}} \times 100
$$

where ASNC is the actual soil nutrients content of the experimental field and ISNC is the initial soil nutrients content of the experimental field.

Thereafter, statistical analysis was done with GENSTAT v.9.2 (Trust, 2007) where analysis of variance (ANOVA) was hence performed by using a general treatment structure (in Randomize Blocks). Least Significance Difference (LSD) was used to compare the means. Hence, differences between treatments were considered at error probabilities $\leq 0.05$.

\section{Results}

\section{Initial soil properties of the long-term experimental field}

The initial physical and chemical properties of the soil of the experimental site surveyed in 2008 are presented in Table 1.

Table 1. Initial soil properties of the long-term experiment site in 2008

\begin{tabular}{lrrr}
\hline & & Soil depths (m) & \multicolumn{1}{c}{0.4} \\
\cline { 2 - 4 } Parameters & \multicolumn{1}{c}{0.1} & 0.2 & \\
\hline Soil texture & & & $73.20 \pm 4.80$ \\
$\quad$ Sand (\%) & $94.60 \pm 0.20$ & $76.50 \pm 4.40$ & $8.30 \pm 1.20$ \\
$\quad$ Silt (\%) & $2.40 \pm 0.10$ & $15.30 \pm 2.00$ & $18.50 \pm 3.90$ \\
$\quad$ Clay (\%) & $3.00 \pm 0.20$ & Sandy loam & Sandy loam \\
Textural class & Sandy & & \\
Soil Chemical properties & & $5.20 \pm 0.08$ & $5.10 \pm 0.06$ \\
pH-H $\mathrm{H}_{2} \mathrm{O}(1: 2.5)$ & $5.10 \pm 0.03$ & $0.19 \pm 0.01$ & $0.14 \pm 0.05$ \\
Organic carbon (\%) & $0.33 \pm 0.04$ & $153.00 \pm 5.00$ & $105.00 \pm 3.00$ \\
Total-N (mg kg-1) & $280.00 \pm 13.00$ & $2.30 \pm 0.10$ & $2.10 \pm 0.20$ \\
Available P (mg kg-1) & $3.70 \pm 0.30$ & $43.00 \pm 6.00$ & $33.00 \pm 5.00$ \\
Exchangeable K (mg kg-1) & $107.00 \pm 40.00$ & &
\end{tabular}

\pm Standard error of mean.

The soil texture was sandy with only 3\% of clay. $6 . \quad$ The Soil Organic Carbon (SOC) content and extractable $\mathrm{P}$ (P-Bray) were all very low with $0.22 \%$ and $2.7 \mathrm{mg}^{\mathrm{kg}}{ }^{-1}$ respectively. The total Nitrogen $(\mathrm{N})$ content was low with 179 mg.kg-1 and soil $\mathrm{pH}\left(\mathrm{H}_{2} \mathrm{O}\right)$ was strongly acidic. These soil characteristics are representative of the soils in Niger that are characterized by sandy texture and lower level of nutrients and organic matter (Ibrahim et al., 2015b). 


\section{Current soil nutrient measurements of the experiment site}

Table 2 illustrates the current soil nutrient content of the experiment site. It is observed that $\mathrm{pH}$ values have decreased compared with the initial values. On the plots applied with NPK as micro-dose, the soil pH value was identic (Table 2) while the mean of pH before trial layout in 2008 was 5.1 (Table1). This indicates that the soil is getting acidic despite the application of the mineral fertilizer micro-dosing. The trend is similar concerning the SOC which remains constant (0.2\%) as average although crop residues are every year left in to the experiment site. It is concluded that this may be due to the production of biomass, which export much nutrient instead of sequestering into the soil. Nevertheless, the dose of available $P$ has increased over time with application of mineral fertilizer micro-dosing with respectively $3.1 \mathrm{mg} . \mathrm{kg}^{-1}$ and $6.1 \mathrm{mg}^{-\mathrm{kg}^{-1}}$ for the between hills and the planting hills. It is observed an increase of available $\mathrm{P}$ at the planting hills compared with between hills. This could be due to the $\mathrm{P}$ accumulation of $\mathrm{P}$ into the soil over time.

Table 2. Current soil chemical properties of the experiment site

\begin{tabular}{llcccrr}
\hline & $\begin{array}{l}\text { Sampling } \\
\text { position }\end{array}$ & pH-H20 & $\begin{array}{c}\text { P Bray1 } \\
\left(\mathrm{mg}^{\mathrm{kg}}{ }^{-1}\right)\end{array}$ & $\begin{array}{c}\text { Total N } \\
\left(\mathrm{mg}_{\mathrm{kg}}{ }^{-1}\right)\end{array}$ & $\begin{array}{c}\text { OC } \\
\left(\mathrm{g} \cdot \mathrm{kg}^{-1}\right)\end{array}$ & $\begin{array}{c}\mathrm{K}^{+} \\
\left(\mathrm{mg}^{\mathrm{k}} \mathrm{kg}-1\right.\end{array}$ \\
\hline Control & Between hill & $4.70 \pm 0.13$ & $2.70 \pm 0.10$ & $141.60 \pm 5.09$ & $1.00 \pm 0.01$ & $45.30 \pm 4.16$ \\
Control & Under hill & $4.80 \pm 0.09$ & $2.50 \pm 0.08$ & $157.30 \pm 10.13$ & $2.00 \pm 0.02$ & $62.80 \pm 5.90$ \\
NPK(6g.hill) & Between hill & $4.60 \pm 0.04$ & $3.10 \pm 0.25$ & $151.60 \pm 10.66$ & $2.00 \pm 0.01$ & $44.00 \pm 4.50$ \\
NPK(6g/hill) & Under hill & $4.60 \pm 0.06$ & $6.10 \pm 0.10$ & $170.50 \pm 11.44$ & $2.00 \pm 0.01$ & $72.80 \pm 0.53$ \\
\hline
\end{tabular}

\pm Standard error of mean.

\section{Changes in soil nutrients content of the experimental field Change in soil $\mathrm{pH}-\mathrm{H}_{2} \mathrm{O}$ of the experimental site}

Figure 1 shows that after 9 seasons of cropping, soil $\mathrm{pH}-\mathrm{H}_{2} \mathrm{O}$ decreased in both the control plot and that applied with $6 \mathrm{~g}$ of NPK (15-15-15) as micro-dose. In the control plot as well as in the fertilized plots, the amplitude of the change in $\mathrm{pH}-\mathrm{H}_{2} \mathrm{O}$ was similar whether the sample was collected between the planting hills or on the hills. When compared with the control plots, soil acidity has increased significantly more on the planting hill than between the hill ( $\mathrm{p} \leq 0.05$ ). Change in soil $\mathrm{pH}$ was $-7.06 \%$ for the control plot and $-9.57 \%$ for the plots applied with NPK. The higher negative percentage of this change indicated that a possible acidification of the soil experiment occurred.

\section{Changes in total nitrogen}

Results concerning change in total $\mathrm{N}$ occurred in the experimental field are presented in Figure 2. Soil total nitrogen content has dropped over the year of cropping in both the control plot and the plot receiving NPK as micro-dose. This negative change in total Nitrogen was more important with respect to between the hills than to the planting hills regardless of the treatment received. The amplitude of nitrogen content drop was lower in the plot applied with NPK than in the control plots. Application of $6 \mathrm{~g}$ of NPK has lowered the amplitude of nitrogen content drop on the planting hill (-5.11\%) compared with the control plot (-12.45\%) indicating partial replenishment compared with the between hills space and the control. Therefore, microdosing option significantly ( $\mathrm{p} \leq 0.005)$ affected Nitrogen content. The negative change might be due to the mobile character of $\mathrm{N}$ into the soil and to the soil nutrient export from biomass production of pearl millet.

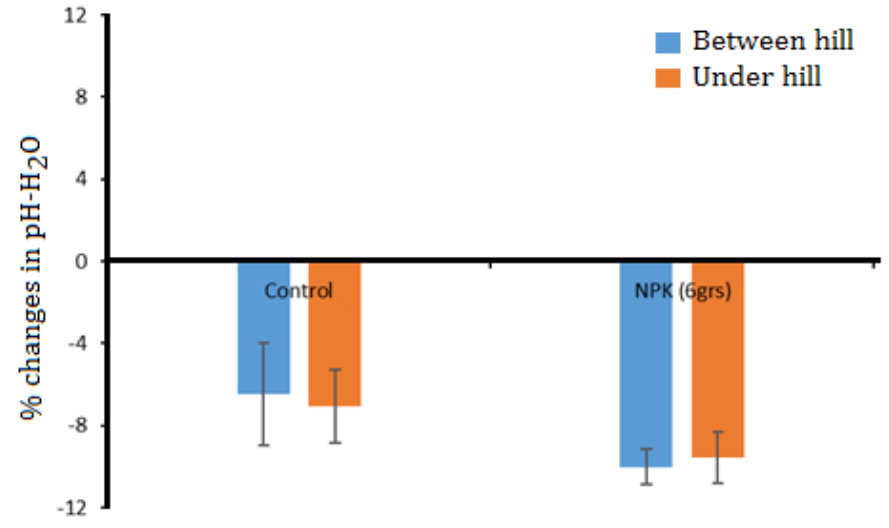

Figure 1. Change in the $\mathrm{pH}\left(\mathrm{H}_{2} \mathrm{O}\right)$ values from 2008 to 2017 of the experiment site as affected by treatments

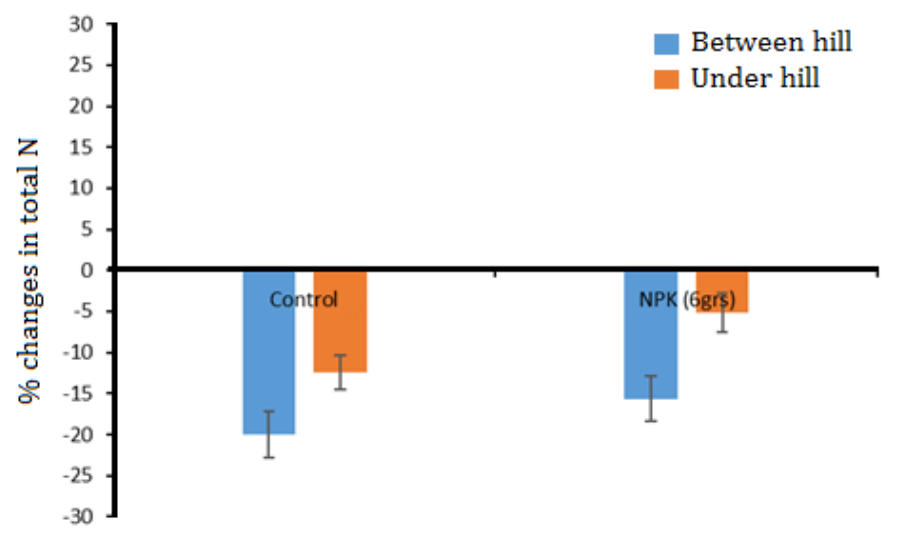

Figure 2. Change in total nitrogen content of the soil as affected by treatments 


\section{Changes in extractable phosphorus (P-Bray1)}

Figure 3 presents the change in extractable phosphorus content of the experimental soil from 2008 to 2017. Higher and positive change was observed in plots applied with NPK compared with the control particularly on the planting hills (88.19 \% vs $-6.27 \%$ ). In both the control and the fertilized plot, positive change was observed in available $\mathrm{P}$ in soil between the planting hills. This is an indication that even though $\mathrm{P}$ export through biomass production has occurred in both treatments, $\mathrm{P}$ accumulation has occurred in the plot applied with NPK. Presumably P mobilization from the soil pool have occurred that was more important on the planting hills.

\section{Change in exchangeable $\mathrm{K}^{+}$}

Figure 4 indicates the change in exchangeable $\mathrm{K}^{+}$of the experimental field. The results showed a positive change on the planting hill and it is significantly higher in plots amended with NPK $(6 \mathrm{~g})$ on planting hill than in the control plots with $19.64 \%$ and $3.18 \%$ respectively in micro-dosing plots and the control plots. Difference between soil sampling positions is significantly different $(\mathrm{p} \leq 0.05)$. The change is however negative in between hills with respectively $-34.6 \%$ and $-25.59 \%$ in fertilizer micro-dosing plots and the control plots respectively. The positive change in exchangeable $\mathrm{K}^{+}$means that this nutrient is gradually stocked in the soil with the application of $6 \mathrm{~g}$ of NPK per hill over time. Nevertheless, the positive change was also observed in the control plots. Thus, this indicates that the accumulation of exchangeable $\mathrm{K}^{+}$is not only from the nutrients applied.

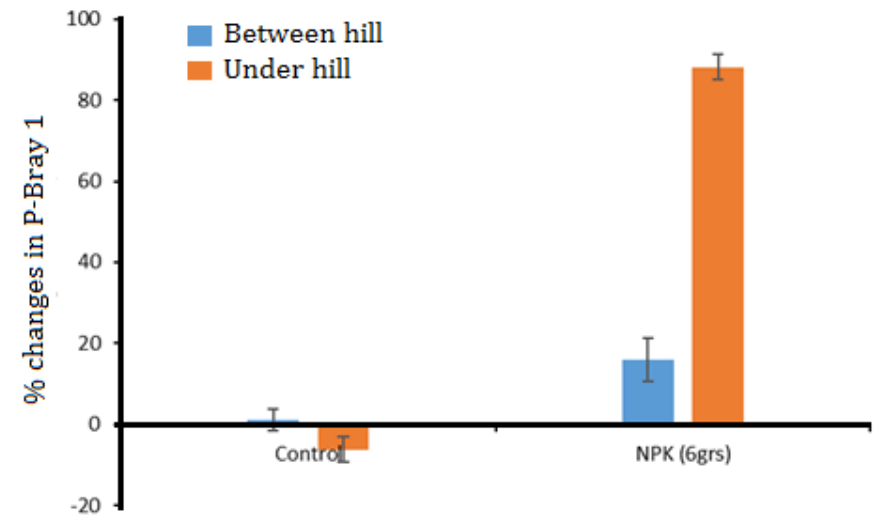

Figure 3. Change in extractable Phosphorus content of the experimental soil as affected by treatments

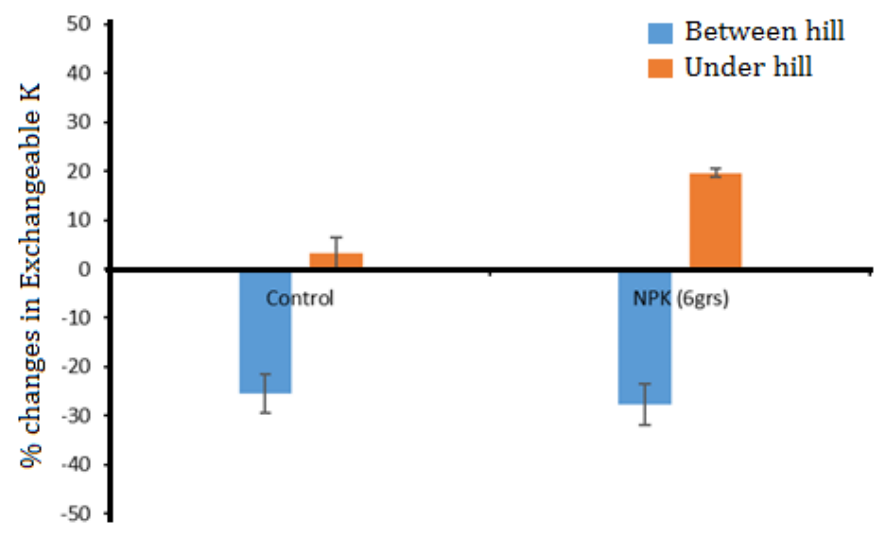

Figure 4. Change in exchangeable $\mathrm{K}+$ content of the experimental soil as affected by treatments

\section{Changes in soil organic carbon}

Results of the changes in organic Carbon of the experimental soil are presented in figure 5 . The proportion of changes in organic Carbon was negative both on planting hill and in between hills space. The trend observed is similar to that of soil pH (Figure1). Results showed that the change was a little bit lower in the fertilized plots compared with the control plots with respectively $-21.85 \%$ and $-26.71 \%$ of change in organic Carbon. The same applies to the between hill where the change was negatively greater in the control plots $(-34.46 \%)$ compared to the micro-dosing plots $(-25.29 \%)$. However, there was no significant difference $(\mathrm{p} \leq 0.05)$ among treatments and soil sampling position as well.

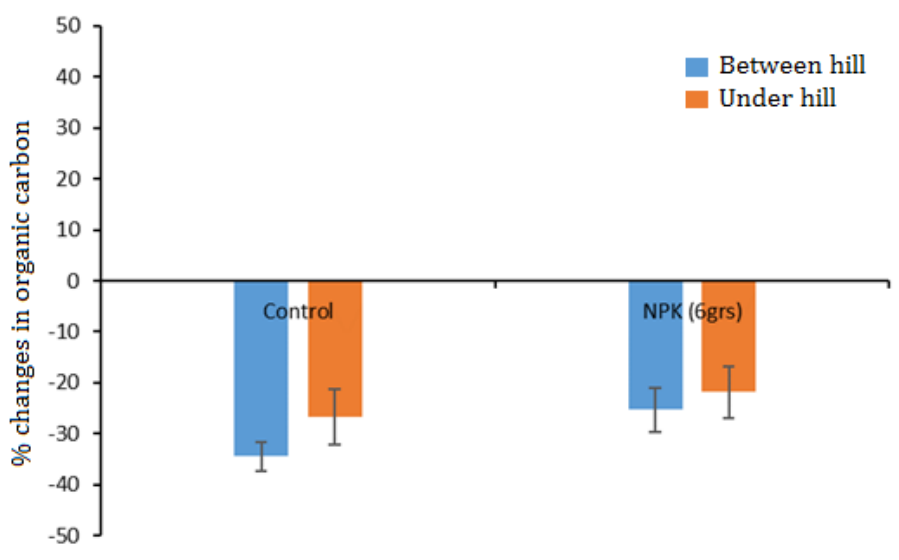

Figure 5. Change in the of organic Carbon content of the experimental soil as affected by treatments 


\section{Effect of mineral fertilizer micro-dosing on pearl millet yield over the two years}

Grain yield and total dry matter of the two years of cropping systems were presented in the Table 3 to illustrate the effect of the mineral fertilizer micro-dosing application. In 2008, mineral fertilizer microdosing technology resulted in increased grain yield and total dry matter production. With respect to grain

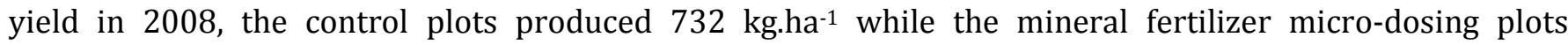
produced 989 kg.ha-1. However, in the 2016; grain yield as well as total dry matter dropped both in the control plots and in the plots treated with $6 \mathrm{~g}$ per hill of NPK with respectively $1196 \mathrm{~kg}^{-h^{-1}} 2987 \mathrm{~kg}^{-1} \mathrm{ha}^{-1}$ whereas in 2008 the control plots and the plots treated with the $6 \mathrm{~g}$ per hill of NPK produced respectively $4118 \mathrm{~kg}$. ha-1 and $6870 \mathrm{~kg}$. ha-1. From the observed trend; grain yield and total dry matter have dropped over time in both the plots amended with micro-dosing and the control plots. This explains that a lone application of mineral fertilizer micro-dosing could not maintain crop yield over time in low-input millet based cropping systems.

Table 3. Millet yields and harvest index

\begin{tabular}{|c|c|c|c|c|c|c|}
\hline & \multicolumn{2}{|c|}{ Grain yield (kg ha-1) } & \multicolumn{2}{|c|}{ Total dry matter $\left(\mathrm{kg} \mathrm{ha}^{-1}\right)$} & \multicolumn{2}{|c|}{$\mathrm{HI}$} \\
\hline & 2008 & 2016 & 2008 & 2016 & 2008 & 2016 \\
\hline Control & $732 \pm 124$ & $146 \pm 22$ & $4118 \pm 419$ & $11960 \pm 204$ & $0.15 \pm 0.01$ & $0.12 \pm 0.01$ \\
\hline Microdose & $989 \pm 132$ & $218 \pm 42$ & $6870 \pm 445$ & $2987 \pm 412$ & $0.14 \pm 0.01$ & $0.07 \pm 0.01$ \\
\hline \multicolumn{7}{|c|}{ Probability values } \\
\hline Year $(Y)$ & $<0.001$ & & $<0.001$ & & 0.003 & \\
\hline Treatment (T) & 0.117 & & $<0.001$ & & 0.037 & \\
\hline $\mathrm{Y} \times \mathrm{T}$ & 0.341 & & 0.072 & & 0.053 & \\
\hline $\mathrm{CV}(\%)$ & 29.8 & & 22.7 & & 13.7 & \\
\hline
\end{tabular}

\pm Standard error of mean.

\section{Discussion}

The soil type of the study area was a Sahelian sandy soil which is inherently fragile and infertile (Bationo et al., 1998). The results of the study were similar to the findings obtained by Housseini (2013) that showed a variation of soil $\mathrm{pH}-\mathrm{H}_{2} \mathrm{O}$ value of about $-0,45$ after applying $1 \mathrm{~g}$ of NPK on the planting hill of sesame farm in Kollo (Niger). These results are in line with the work of Bandoum (2005) where he showed that mineral fertilizer micro-dosing caused nutrient export initially present in the soils. These results also agreed the findings obtained by Ibrahim et al. (2016) who found that fertilizer micro-dosing with (2 g DAP and $6 \mathrm{~g}$ NPK) had a negative effect on both partial and full nutrient balance in pearl millet field. Added to that, the work of Housseini (2013) confirmed that total dry matter of sesame local variety seriously exported partial nutrient balance with about $21.9 \mathrm{~g} / \mathrm{kg} \mathrm{N}$ with application of NPK at hill. Therefore, it is concluded that mineral fertilizer micro-dosing has led to a negative contribution with regard to partial and full soil nutrient balances instead of increasing such nutrient balances. However, Ibrahim et al. (2016) reported that a combined use of fertilizer micro-dosing along with manure had a positive partial nutrient balance. This indicates that pearl millet used significantly much more nutrients from the native soil nutrients. On the other hand, the highest percentage of change observed between hills may be due to the lateral root development of pearl millet that permit to the plant to look for nutrients far from the hill. This is a strategy of pearl millet adopted so as to benefit from nutrients where they are concentrated (Ibrahim et al. 2015b). With such nutrient mining character of fertilizer micro-dosing, cropping system could not be quite sustainable meaning that the technology cannot sustain the nutrient requirements of pearl millet over time. Research has shown that $\mathrm{pH}$, $\mathrm{Fe}, \mathrm{Al}$ and $\mathrm{Ca}$ concentration as well as soil texture and organic matter significantly affect $\mathrm{P}$ availability for the plant (Mkhabelaa and Warman, 2005). In acidic soils and particularly with sandy structure like the one of our experiment with up to $47 \%$ aluminium saturation (Fatondji et al., 2006), it is expected that $\mathrm{P}$ immobilization occurs at $\mathrm{pH}$ lower than 5. In the sampled plots, soil $\mathrm{pH}$ has dropped from 5 to 4.8 (Figure1). Some studies (Bationo et al., 2003, 2011) revealed that the accumulation of $\mathrm{K}^{+}$in the soil is that the native Sahelian soils in Sadoré contains a high percentage of exchangeable cations such as $\mathrm{K}^{+}$, $\mathrm{Ca}^{2+}$. Ibrahim et al. (2016) observed that nutrient depletion is the great consequence of the export of nutrients of crop residue. Though crop residues are usually left in the experimental field over the years, we realize that the change in organic Carbon was relatively negative. First, this may be due to the rapid mineralization of organic matter over time of the soil as it is a Sahelian sandy soil which is fragile and inherently infertile and hence its organic matter rate is very low $(<1 \%)$. Most importantly, lack of application of organic manure over time in the experimental field can exacerbate the drastic decrease of organic Carbon in the long term. Ibrahim et al. (2015b) indicated that a combination of organic manure with fertilizer micro-dosing is necessary in the long 
term so as to increase and sustain pearl millet yield as well as efficient use of limited nutrients such as soil organic Carbon in Sahelian cropping systems.

Yield reduction observed over time shown in the experiment is in line with the work of Adams et al. (2016), who demonstrated negative yield trends of fertilizer micro-dosing treatments indicating that mineral fertilizer alone is unstainable at Sadoré. However, crop residue or manure addition at a certain level buffered pH by 0.3 and increased pearl millet yield. A combined application of manure and mineral fertilizer enhances increased grain yield in Sahel (de Rouw and Rajot 2004; Ibrahim et al., 2015a; Suzuki et al., 2016). Earlier manure application is favourable for root system development (Michels and Bielders, 2006) and allows faster initial leaf growth, thereby increasing water use efficiency and crop productivity (Shapiro and Sanders, 1997; Bationo et al., 1998). Similarly, in Sahelian cropping system, many studies have shown the importance of crop residue in the Sahel Region. Buerket et al. (2000) reported that $73 \%$ of millet grain yield increase was due to application of 2 t.ha $^{-1}$ of millet residue. Many studies have reported increased soil permeability and aggregate stability as well as increased water infiltration and water holding capacity, increased soil organic matter (SOM), pH, CEC and nutrient availability which can lead to sustainable yield and sustained soil fertility over time (Bationo and Mokwunye, 1991; Buerkert and Hiernaux, 1998).

Overall, this yield reduction over time might be attributed to fast nutrient release and organic matter decomposition reported for Sahelian conditions (Bationo et al., 2005; Manyame, 2006). In addition to soil fertility decline, other environmental factors such as dry spell periods might be bringing about a drop of total biomass production over time. On the other hand, recurrent dry spell periods observed in Sadoré over the years coinciding with critical peal millet growth in this season including the grasshopper attack which has led to a replanting of the whole field (Sani, 2018).

\section{Conclusion}

The change in soil nutrients obtained in this study showed that fertilizer micro-dosing stimulates the export of soil nutrients that are initially into the soil which consequently encourages the soil impoverishment. Thus, fertilizer micro-dosing significantly affects soil nutrients in the long term. It is concluded that the trend of the change in soil $\mathrm{pH}-\mathrm{H}_{2} \mathrm{O}$ as well as in soil organic carbon, and in total nitrogen content were negative. However, only Phosphorus and exchangeable $\mathrm{K}+$ have presented positive change. The change in soil nutrients dynamics is better on the planting hills than that from between hills space. Further, pearl millet yield dropped over time regardless of the treatments applied with mineral fertilizer micro-dosing. Hence, we concluded that crop yield was not only affected by micro-dosing options but also environmental factors were included. Similarly, the study concluded that the hill placement character greatly influences soil nutrients dynamics in long-term application of micro-dosing. Further research should be implemented in order to thoroughly assess the sustainability of that technology.

\section{Acknowledgements}

The German Federal Ministry of Education and Research (BMBF) through West African Science Service Centre on Climate Change and Adapted Land Use (WASCAL) funded this research. We are also grateful to ICRISAT-Niamey for the facilities placed to our disposal. Especially, we are most thankful to ICRISAT staff Laouali Issaka and Moustapha Adamou for their technical assistance during our data collection. We are also grateful to Dr Saratu Ibrahim of WASCAL MRP/FUT Minna/Nigeria for her support.

\section{References}

Adams, A.M., Gillespie, A.W., Kar, G., Koala, S., Ouattara, B., Kimaro, A.A., Bationo, A., Akponikpè, P.B.I., Schoenau, J.J. Peak, D., 2016. Long term effects of reduced fertilizer rates on millet yields and soil properties in the WestAfrican Sahel. Nutrient Cycling in Agroecosystems 106(1): 17-29.

Akponikpè, P., 2008. Millet response to water and soil fertility management in the Sahelian Niger : Experiments and Modeling. PhD Thesis Universite Catholique de Louvain, Louvain. 200 p.

Akponikpè, P., Gérard, B., Bielders, C., 2014. Soil water crop modeling for decision support in millet- based systems in the Sahel : A Challenge, African Journal of Agricultural Research 9(7): 1700-1713.

Aune, J.B., Ousman, A., 2011. Effect of seed priming and microdosing of fertilizer on sorghum and pearl millet in Western Sudan. Experimental Agriculture 47(3): 419-430.

Bagayoko, M., Maman, N., Palé, S, Sirifi, S., Taonda, S.J.B., Traore, S., Mason, S.C., 2011. Microdose and N and P fertilizer application rates for pearl millet in West Africa. African Journal of Agricultural Research 6(5):1141-1150.

Bandoum, Y., 2005. Effets de la fertilisation par micro dose sur la productivité du mil, les bilans des nutriments et de l'eau du sol au Niger. Mémoire de fin d'étude de Maitrise en Sciences Agronomiques. Faculté d'Agronomie, Université Abdou Moumouni, Niger pp. 1-57.

Bationo, A., Mokwunye, A.U., 1991. Role of manures and crop residue in alleviating soilfertility constraints to crop production: With special reference to the Sahelian and Sudanianzones of West Africa. Fertilizer Research 29(1): 
117-125.

Bationo, A., Lompo, F., Koala, S. 1998. Research on nutrient flows and balance in west Africa: State-of-the-Art. Agriculture, Ecosystems and Environment 71(1-3): 19-35.

Bationo, A., Ntare, B., 2000. Rotation and nitrogen fertilizer effects on pearl millet, cowpea and groundnut yield and soil chemical properties in a sandy soil in the semi-arid tropics, West Africa. The Journal of Agricultural Science 134(3): 277-284.

Bationo, A., Buerkert, A., 2001. Soil organic carbon management for sustainable land use in Sudano-Sahelian West Africa. Nutrient Cycling in Agroecosystems 61(1-2): 131-142.

Bationo, A., Mokwunye, U., Vlek, P. L., Koala, S., Shapiro, B. I. 2003. Soil fertility management for sustainable land use in the West African Sudano-Sahelian zone. In: Soil fertility management in Africa: A regional perspective, Gichuru, M.P., Bationo, A., Bekunda, M.A., Goma, H.C., Mafongoya, P.L., Mugendi, D.N., Murwira, H.K., Nandwa, S.M., Nyathi, P., Swift, M.J., (Eds.). Academy Science Publishers (ASP); Centro Internacional de Agricultura Tropical (CIAT); Tropical Soil Biology and Fertility (TSBF), Nairobi, Kenya. pp. 253-292.

Bationo, A., Kihara, J., Ouattara, B., Vanlauwe B., 2005. Technologies for sustainable management of sandy Sahelian soils. In: Management of tropical sandy soils for sustainable agriculture. "A holistic approach for sustainable development of problem soils in the tropics" FA0, Khon Kaen, Thailand. Available at [access date: 08.02.2019]: http://www.fao.org/3/AG125E00.htm\#Contents

Bationo, A., Kihara, J., Adesina, A., 2012. Beyond biophysical recommendations: towards a new paradigm. In: Improving soil fertility recommendations in Africa using the decision support system for agrotechnology transfer (DSSAT). Kihara, J., Fatondji, D., Jones, J.W., Hoogenboom, G., Tabo, R., Bationo, A. (Eds.). Springer Dordrecht pp. 169-184.

Bielders, C., 2015. Microdose fertilisation : A step on the ladder towards crop intensification in the Sahel ? Earth and Life Institute, 1-11.

Blessing, O.C., Ibrahim, A., Safo, E.Y., Yeboah, E., Robert, C., Logah, V., Monica, U.I., 2017. Fertilizer micro-dosing in West African low-input cereals cropping: Benefits, challenges and improvement strategies. African Journal of Agricultural Research 12(14): 1169-1176.

Buerkert, A., 1995. Effects of Crops Residues, Phosphorus, and Spatial Soil Variability on Yield and Nutrient Uptake of PearI Millet (Pennisetum glaueum (L.) R. Br.) in Southwest Niger. PhD Thesis. Universität Hohenheim, 70593 Stuttgart, Germany. 284p.

Buerkert, A., Hiernaux, P., 1998. Nutrients in the West African Sudano-Sahelian zone: Losses, transfers and the role of external inputs. Zeitschrift für Pflanzenernährung und Bodenkunde 161(4): 365-383.

Camara, B., Camara, F., Berthe, A., Oswald, A., 2013: Micro-dosing of fertilizer: A technology for farmers' needs and resources. International Journal of AgriScience 3(5): 387-399.

de Rouw, A., Rajot, J-L., 2004. Nutrient availability and pearl millet production in Sahelian farming systems based on manuring or fallowing. Agriculture, Ecosystems and Environment 104(2): 249-262.

Fatondji, D., Martius, C., Bielders, C., Vlek, P.L.G., Bationo, A., Gerard, B., 2006. Effect of planting technique and amendment type on pearl millet yield, nutrient uptake, and water use on degraded land in Niger. Nutrient Cycling in Agroecosystems 76(2-3): 203-217.

Gaston, S., Dahiratou, I.D., Moussa, B., Dougbedji, F., 2016. Contribution of previous legumes to soil fertility and millet yields in West African Sahel. African Journal of Agricultural Research 11(28): 2486-2498.

Hayashi, K., Abdoulaye, T., Gerard, B., Bationo, A., 2008. Evaluation of application timing in fertilizer micro-dosing technology on millet production in Niger, West Africa. Nutrient Cycling in Agroecosystems 80(3): 257-265.

Houba, V., van der Lee, J., Novozamsky, I., 1995. Soil analysis procedures; Other Procedures (Soil And Plant Analysis, Part 5B). Department of Soil Science and Plant Nutrition, Wageningen Agricultural University, Wageningen, The Netherlands, 217p.

Housseini, M.L.R., 2013. Effet de la fertilisation par microdose sur la productivité de des teneurs et les bilans partiels des nutriments. Memoire de fin d'études en vue de l'obtention du diplome de Master 2 en Gestion de Fertilité des Sols. Universite Polytechnique de Bobo- Dioulasso pp. 1-64.

Ibrahim, A., Pasternak, D., Fatondji, D., 2015a. Impact of depth of placement of mineral fertilizer micro-dosing on growth, yield and partial nutrient balance in pearl millet cropping system in the Sahel. The Journal of Agricultural Science 153(8): 1412-1421.

Ibrahim, A., Clement, R., Fatondji, D., Opoku, A., 2015b. Hill placement of manure and fertilizer micro-dosing improves yield and water use efficiency in the Sahelian low input millet-based cropping system. Field Crops Research 180: 29-36.

Ibrahim, A., Abaidoo, R.C., Fatondji, D., Opoku, A., 2016. Fertilizer micro-dosing increases crop yield in the Sahelian lowinput cropping system: A success with a shadow. Soil Science and Plant Nutrition 62(3): 277-288.

ICRISAT, 2009. Fertilizer microdosing: boosting production in unproductive lands. documentation. International Crops Research Institute for Semi-Arid Tropics, Patancheru, Andhra Pradesh India. Available at [access date: 08.02.2019]: http://oar.icrisat.org/5666/1/Microdosing_Flyer_2009.pdf

Idrissa, A.M., 2010. La simulation des composantes du rendement du mil sous la fertilisation par micro dose en utilisant le modèle DSSAT. Mémoire de fin d'études En vue de l'obtention du diplôme d'Ingénieur d'Etat en Sciences Agronomiques. Université Ibn Khaldoun de Tiaret Faculté des Sciences Agronomiques et Veterinaires, Alger. 62p.

Manyame, C., 2006. On-farm yield and water use response of pearl millet to different management practices in Niger. PhD Thesis. Office of Graduate Studies of Texas A\&M University. 126p. 
Michels, K., Bielders, C.L., 2006. Pearl millet growth on an erosion-affected soil in the Sahel. Experimental Agriculture 42(1): 1-17.

Mkhabelaa, M.S., Warman, P.R., 2005. The influence of municipal solid waste compost on yield, soil phosphorus availability and uptake by two vegetable crops grown in a Pugwash sandy loam soil in Nova Scotia. Agriculture, Ecosystems \& Environment 106(1): 57- 67.

Sani, I.M.S, 2018. Soil nutrient dynamics under long term application of mineral fertilizer micro-dosing to pearl millet [Pennisetum glaucum (L.) R. Br.] on a Sahelian sandy soil of Niger Republic. Master of Techonology Thesis. Federal University of Technology Minna (FUT Minna). Niger State, Nigeria. 129p.

Shapiro, B.I., Sanders, J.H., 1998. Fertilizer use in semiarid West Africa: Profitability and supporting policy. Agricultural Systems 56(4): 467-482.

Sime, G., Aune, J.B., 2014 Maize response to fertilizer dosing at three sites in the Central Rift Valley of Ethiopia. Agronomy 4(3): 436-451.

Sommer, R., Bossio, D., Desta, L., Dimes, J., Kihara, J., Koala, S., Mango, N., Rodriguez, D., Thierfelder, C., Winowiecki, L., 2013. Proftable and sustainable nutrient management systems for East and Southern African smallholder farming systems: challenges and opportunities: a synthesis of the Eastern and Southern Africa situation in terms of past experiences, present and future opportunities in promoting nutrients use in Africa. Cali (Colombia). CIAT. The University of Queensland. QAAFI. CIMMYT. 91p. Available at [access date: 08.02.2019]: https://repository.cimmyt.org/handle/10883/4035

Suzuki, K., Mastunaga, R.., Hayashi, K.., Mastumoto, N., Tobita, S.., Bationo, A.., Okada, K., 2016. Long-term effects of fertilizer and organic matter application on millet in Niger. Agronomy Journal 108(2): 873-883.

Suzuki, K., Matsunaga, R., Hayashi, K., Matsumoto, N., Tobita, S., Bationo, A., Okada, K., 2017. Effects of long-term application of mineral and organic fertilizers on dynamics of nitrogen pools in the sandy soil of the Sahel region, Niger. Agriculture, Ecosystems and Environment 242: 76-88.

Tabo, R., Bationo, A., Diallo, M.K., Hassane, O., Koala, S. 2005. Fertilizer micro-dosing for the prosperity of small-scale farmers in the Sahel: Final report - Fertilisation par micro-dose pour la prospérité du petit paysan au Sahel: Rapport Final. Niamey, Niger: International Crops Research Institute for the Semi-Arid Tropics. 28 p. Available at [access date: 08.02.2019]: https://cgspace.cgiar.org/handle/10568/17024

Trust, L., 2007. Genstat. Lawes Agricultural Trust (Rothamsted Experimental Station), Rothamsted, UK.

Twomlow, S., Mugabe, F.T., Mwale, M., Delve, R., Nanja, D., Carberry, P., Howden, M., 2008. Building adaptive capacity to cope with increasing vulnerability due to climatic change in Africa - A new approach. Physics and Chemistry of the Earth, Parts $A / B / C$ 33(8-13): 780-787.

Van Reeuwijk, L.P., 2002. Procedures for soil analysis. Technical Paper 9. 6th Edition. International Soil Reference and Information Centre (ISRIC) \& Food and Agricultural Organization of the United Nations (FAO). Wageningen, The Netherlands.

Walkley, A., Black, I.A., 1934. An examination of Degtjareff method for determining soil organic matter and a proposed modification of the chromic acid titration method. Soil Science 37(1): 29-37..

West, L., Wilding, L, Landeck, J., Calhoun, F.G., 1984. Soil survey of the ICRISAT Sahelian Center, Niger, West Africa. Soil and Crop Sciences Department/TropSoils, Texas A\&M University System, College Station, Texas, USA. 82p. Available at [access date: 08.02.2019]: https://pdf.usaid.gov/pdf_docs/PNAAQ419.pdf 